\title{
Geneza konfliktu etiopsko-erytrejskiego
}

\author{
Seifu Gebru \\ Institute of Linguistics, Adam Mickiewicz University \\ ul. Międzychodzka 5, 60-371 Poznań, POLAND
}

\begin{abstract}
The source of Ethio-Eritrean conflict was Italian colonization of Eritrea officially in 1890. Eritrea was an integral part of Ethiopia and it was very attractive for foreign intervention because of being situated on the coast of the Red Sea. It was treated as a military base to attack and occupy whole Ethiopia. In 1896 and in 1935-1936, Eritreans were forced to fratricidal fights. After Italian defeat during WWII in 1941 Eritrea fell under British administration and different parties were formed at the time. On the basis of the United Nations' resolution in 1952, the Ethiopian-Eritrean Federation came into being which meant discrimination and emigration for many Eritreans. Lastly in 1962, Eritrea became a province of Ethiopia which led to a bloody war lasting 30 years. During the war separation feeling became very strong among Eritreans and their hate to Ethiopians increased because of their persecution by the Ethiopian government. In 1991 Eritrea won the war and in 1993 became a state. Then, a conflict between two former friends that means the leader of Tigray People's Liberation Front (TPLF), the later Prime Minister of Ethiopia, Melese Zenawi and the President of Eritrea Issayas Afewerki brought a new bloody war in 1998.
\end{abstract}

\section{Aspekt historyczny}

Północne rejony Etiopii wraz z Erytrea stanowią historyczną kolebkę państwa etiopskiego. Odegrały one poważną rolę $\mathrm{w}$ procesie formowania się państwowości oraz tworzenia się jego bogatej kultury. Bliskość Morza Czerwonego, które po otwarciu Kanału Sueskiego stało się jednym z najważniejszych szlaków morskich, sprawiła, że obszar ten ogromnie zyskał na atrakcyjności. Jest to rejon strategiczny, w którym często dochodziło do konfliktów. Wszystkie próby podbicia Etiopii zaczynały się zawsze od wybrzeża Morza Czerwonego, czyli od strony Erytrei (Erytrea z greckiego - czerwony). Etiopia, broniąc dostępu do morza, walczyła m.in. z Egiptem, Sudanem (powstanie Mahdystów), Turcja, Anglią i Włochami. Do historii wielkich bitew przeszły takie miejsca jak: Debarwa, Gundet, Gura, Kufit, Saati, Dogali i Koatit. Zwycięstwa w nich zawsze odnosili Etiopczycy.

Etiopia należy do jednych z najstarszych cywilizacji świata. W jej blisko trzytysięcznej historii tereny dzisiejszej Erytrei odgrywały zawsze bardzo ważną rolę, stanowiąc prawdziwe okno na świat. Jak donoszą historycy, już ok. V w. p.n.e. w północnej części Erytrei, na wybrzeżu Morza Czerwonego powstały kolonie kupców i osadników z południowoarabskiego państwa Saba (od nich wywodzi się grupa semicka, do której zaliczają się Amharowie, Gurage oraz Tigrajczycy, którzy stanowią większość ludność Erytrei. Przynieśli oni ze sobą wysoko rozwiniętą kulturę techniczną i intelektualna, dając w ten sposób początek cywilizacji etiopskiej, zwanej również aksumską. Zbudowany ok. II w. p.n.e. nad Morzem Czerwonym port Adulis (w pobliżu dzisiejszego portu Massaua) był bardzo ważnym centrum handlowym. Przez port ten eksportowano m.in. kość słoniowa, skórę hipopotamów, a także niewolników do Egiptu, krajów arabskich, Persji i Indii. Dzięki kwitnącym tam kontaktom handlowym stanowił on ważny punkt wzajemnego 
oddziaływania i przenikania się różnych kultur i języków, co sprzyjało ogólnemu rozwojowi kraju i miało ogromny wpływ na formowanie się tak niezwykle bogatej i interesującej cywilizacji. Nic dziwnego, że stanowił takomy kasek i wielokrotnie był okupowany, między innymi przez Egipcjan i Turków, którzy tą drogą próbowali wtargnąć w głąb Etiopii. Próby te zawsze kończyły się fiaskiem.

Około I w. n.e. na terenie północnej Etiopii powstało państwo Aksum, które w krótkim czasie nabrało bardzo dużego znaczenia ekonomicznego, politycznego i kulturalnego, odgrywając ważną rolę na międzynarodowej arenie.

Właśnie drogą morską poprzez Morze Czerwone dotarła do Aksum religia chrześcijańska, którą w 333 r. oficjalnie przyjął król Ezana. W VI w. n.e. władca państwa Aksum Kaleb, wraz z flotą cesarza Bizancjum Justynianana, pod hasłem szerzenia religii chrześcijańskiej, podbił terytorium Arabii Południowej oraz Jemen (517 r.).

W roku 570 wojska państwa Aksum dotarły do Mekki, gdzie poniosły dotkliwą klęskę, która stała się jedną z przyczyn utraty potęgi przez to państwo. W VII w. n.e. powstał islam - religia, która gwałtownie rozpowszechniła się także w Północnej Afryce. Wyznawcy islamu opanowali wyspy Dahlak (dziś należące do Erytrei) oraz port Massaua, który dla chrześcijańskiego państwa Aksum miał kluczowe znaczenie. Swobodny handel poprzez wybrzeże Morza Czerwonego został zahamowany, co ostatecznie doprowadziło do upadku Aksum.

Natomiast religia muzułmańska zaczęła rozpowszechniać się i umacniać na afrykańskim wybrzeżu Morza Czerwonego. Konfrontacja tych dwóch potężnych religii stała się źródłem do dziś trwającego konfliktu, który najbardziej zaznaczył się w erze kolonializmu.

Po upadku państwa aksumskiego (ok. X w. n.e.), ośrodek władzy państwa etiopskiego stopniowo przesunął się bardziej na południe. Nastapiło osłabienie władzy centralnej i rozbicie dzielnicowe. Od tej pory państwo etiopskie formalnie (z kilkoma zaledwie wyjątkami) działało na zasadzie luźnej federacji poszczególnych dzielnic, mających dużą samodzielność, posiadających faktycznie prawie suwerennych władców, jednakże zawsze podporządkowanych jednemu cesarzowi tzw. królowi królów.

Na zewnątrz Etiopia uznawana była za jedno państwo, wewnątrz jednak była mocno podzielona przez działalność bardzo silnych ruchów separatystycznych w poszczególnych dzielnicach, w tym także w rejonach północnych należących do dzisiejszej Erytrei.

Jednak cesarz w wypadku odmówienia posłuszeństwa, nie wahał się podjąć interwencji zbrojnej. Pomimo silnej rywalizacji lokalnych władców, w przypadku zewnętrznej interwencji potrafili się zjednoczyć i zmobilizować siły przeciwko najeźdźcy. W przypadkach innych niż zagrożenie państwa cesarz praktycznie nie ingerował w działalność poszczególnych regionów. Stąd zapewne niechęć do silnej scentralizowanej władzy i pojawianie się kolejnych ruchów separatystycznych, które można uznać za jedną z przyczyn dzisiejszego podziału na Etiopię i Erytreę.

Zaledwie kilku cesarzy w całej historii Etiopii próbowało zmienić ten stan i scentralizować władzę oraz ujednolicić kraj. Należał do nich cesarz Zera Jaykob (1434 - 1468), który był jednym z najwybitniejszych władców Etiopii. Prowadził on politykę opartą na silnej, scentralizowanej władzy. Zdawał sobie sprawę, jak ważny jest dla kraju dostęp do morza, dlatego skupił się przede wszystkim na wyparciu islamistów z północno-wschodnich terenów i odzyskał dla Etiopii wybrzeże Morza Czerwonego. W celu wzmocnienia chrześcijańskiego państwa, na północy wciąż zagrożonego przez Islam, i zachowania nadmorskich terenów, podniósł pozycję tamtejszego kościoła oraz rangę i znaczenie zarządcy tych terenów nadając mu tytuł Bahier Negasz tzn. królujący nad morzem. Rozkazem cesarskim objął on władzę nad dzisiejszą Erytrea, nazywając ten obszar również Bahier Negasz. Zarządca miał kontrolę nad dostępem do morza oraz nad szlakami handlowymi wiodącymi na północ kraju, co dawało mu władzę prawie dorównującą cesarzowi.

Po śmierci cesarza Zera Jaykoba, jego następcy nie przywiązywali takiej wagi do centralizacji państwa i akceptowali luźną federację dzielnic podległych cesarzowi. Musiało upłynąć kilka wieków, aby Ras Kasa, jako cesarz Teodor II (1855 - 1867) ponownie pokusił się o utworzenie silnej władzy centralnej. Przeprowadził wiele reform ograniczających samowładzę w poszczególnych dzielnicach, ale tak naprawdę dopiero cesarzowi Menelikowi II (1889 - 1913) udało się scentralizować państwo. Uważany jest za ojca współczesnego, nowoczesnego państwa 
etiopskiego i powszechnie uznawany za bohatera narodowego. Ustanowił obecne granice państwa, jednakże w sprawach dotyczących Erytrei popełnił poważny błąd, o czym będzie mowa w dalszej części.

\section{Początki i przyczyny ekspansji kolonialnej na terenie Erytrei}

Podbój Afryki przez kolonizatorów miał negatywny wpływ na kulturę i rozwój rdzennej ludności. Zdobywcy starali się zniszczyć wszystko, co zastali na swojej drodze. Nie brali pod uwagę interesów mieszkańców podbijanych terenów, kierując się realizacją własnych celów ekonomicznych. Prowadzili na podbitych terenach gospodarkę rabunkową, wykorzystując bogactwa naturalne i tanią siłę roboczą do rozwoju gospodarczego własnych państw.

Na terenach podbitych można było bezkarnie nawracać ,pogan” na religię wyznawaną przez kolonizatorów, co obrazują słowa wybitnego działacza antykolonialnego, późniejszego prezydenta Kenii Jomo Keniaty: Kiedy kolonizatorzy przybyli do Afryki mieli tylko Biblie, kazali nam się modlić z zamkniętymi oczami. Kiedy otworzyliśmy oczy my mieliśmy ich Biblię, oni mieli nasza ziemię.

Kolonizatorzy wyznaczyli sztuczne granice, które często nie miały nic wspólnego z poprzednimi, kształtującymi się przez wieki, naturalnymi granicami terytoriów, uwzględniających różnice językowe, etniczne i kulturowe. I tak, na przykład, Somalijczycy, dzięki tej polityce znaleźli się na terenie kilku państw: Etiopii, Kenii, Somalii i Dżibutii. Taki niezwykle konfliktogenny podział na zasadzie dziel i rządź spowodował krwawe wojny regionalne na tle etnicznym, które pochłonęły setki tysięcy ofiar i do dziś nękają Afrykę.

Kiedy powstała Organizacja Jedności Afryki (OJA), która - w celu uniknięcia wojen przyjęła w swojej Karcie zasadę, że nowe państwa, które uzyskują niepodległość, muszą uznać granice, jakie istniały w momencie uzyskania przez nie suwerenności. Niestety, nie wszystkie kraje zastosowały się do niej. Jako przykład można tu podać wojny między Etiopią a Somalią oraz konflikt między Etiopią a Erytrea.

Wskutek strategicznego położenia Etiopii, graniczącej od północy (dzisiaj terytorium Erytrei) z Morzem Czerwonym, była ona niejako skazana na ekspansję wielu państw o kolonialnych ambicjach. W XVI w. Turcy Otomańscy rozszerzyli swoje kolonie, zajmując port Massaua i sięgając w głąb aż do dzisiejszego Keren, utrudnili Etiopii dostęp do Morza Czerwonego. Później nastapiła ekspansja egipska, która objęła w 1847 r. port Massaua oraz część dzisiejszej Erytrei. W latach 1875 - 1879 doszło do wielu starć między wojskami etiopskimi cesarza Jana IV a Egipcjanami. Egipcjanie przegrali kilka bitew, m.in. pod Gundet, Garay, Doghali, i wycofali się z większości okupowanych terenów. Port Massaua pozostał jednak w ich rękach, a w rzeczywistości pod kontrolą Anglików, którzy w tym czasie sprawowali protektorat nad Egiptem.

Po wybuchu powstania Mahdystów w Sudanie, skierowanego przeciw okupacji egipskiej, czyli angielskiej (Egipt znajdował się pod protektoratem Anglii), nastapiła ekspansja Islamu na chrześcijańskie tereny Etiopii, obejmujące tereny dzisiejszej Erytrei. Oddziaływanie Mahadystów, głoszących świętą wojnę islamu przeciwko niewiernym, zaniepokoiło Anglików, którzy zaczęli bać się o swoje interesy w tym rejonie. Dlatego 3 VI 1884 r. został podpisany traktat etiopskoangielski, który dawał Etiopii dostęp do wolnego handlu w porcie Massaua (należał on w tym czasie do Anglików), a Anglii koncesję na uprawę bawełny i indygo. Anglicy zobowiązali się do udzielenia Etiopii pomocy w wypadku agresji zewnętrznej.

Pomimo wzajemnego wsparcia cesarz Jan IV przegrał z Mahdystami bitwę pod Metemma 1889 r. Nie miało to jednak większego znaczenia, ponieważ powstanie Mahadystów w związku $\mathrm{z}$ ich problemami w Sudanie upadło.

\section{Ekspansja włoska w Erytrei}

Po otwarciu 17 XI 1869 r. Kanału Sueskiego wzrosło zainteresowanie wybrzeżem Morza Czerwonego ze strony Europejczyków. Dlatego już w tym samym roku włoska firma żeglarska Rubattino za pośrednictwem mnicha Giuseppe Sapeto kupiła od lokalnego sułtana niewielki teren przy brzegu Morza Czerwonego dzisiejszy port Assab. Obszar ten następnie przejął rząd włoski, chcąc umocnić swoje wpływy w tym rejonie. 
Jak wiadomo miedzy kolonizatorami istniała silna rywalizacja, zwłaszcza między Francuzami i Anglikami. Ci ostatni mieli plan podporządkowania sobie Afryki od Kairu po Przylądek Dobrej Nadziei, Francuzi natomiast chcieli zając Afrykę od zachodniego do wschodniego wybrzeża. Jak wynikało z tych planów, w obszarze zainteresowania obu tych mocarstw leżało podporządkowanie sobie Etiopii. Dlatego Anglia szukała sprzymierzeńca. Wybór padł na Włochów, którym Anglicy w 1885 r. oddali port Massaua.

W ten sposób Włosi uzyskali dwa bardzo ważne porty: Assab w południowej i Massaua w północnej części dzisiejszej Erytrei. Miało to decydujący wpływ na dalsze losy tego obszaru. Włosi stopniowo powiększali swoje terytorium, dążąc do połączenia obu portów oraz próbując sięgnąc w głąb Etiopii.

Zaniepokojony cesarz Jan IV postanowił przeciwstawić się tej ekspansji. Włosi zaś usilnie próbowali osłabić władzę w Etiopii. Niespodziewanie znaleźli sprzymierzeńca w królu regionu Shoa (obszar dzisiejszej centralnej Etiopii), Meneliku II, który miał ambicje zostać królem królów, czyli cesarzem całej Etiopii. W 1883 r. potajemnie zawarli układ, w którym Włosi zobowiazali się do udzielenia zbrojnej pomocy w zdobyciu tronu cesarskiego, licząc po cichu na wybuch wojny domowej, która osłabiłaby kraj, a im ułatwiła kolonizację. Jan IV, który uważał, że dostęp do morza jest sprawą priorytetowa, a jednocześnie chcąc uniknąc wojny, próbował pokojowo załagodzić spór. Poprosił o pomoc Anglię, powołując się na wcześniej zawarty traktat o wzajemnej pomocy. Jednak w interesie Anglików było wspieranie Włochów. Gdy zawiodła dyplomacja, Jan IV postanowił użyć siły, jednak nie miał on żadnych szans na zwycięstwo, ponieważ od strony południowej zagrożony był przez Menelika II, a na północy wdał się w wojnę z Mahdystami, podczas której zginął w $1889 \mathrm{r}$.

Wojna z Mahdystami przyniosła korzyści przede wszystkim Włochom. Wojska etiopskie, które do tej pory stawiały opór ekspansji włoskiej, zadając nawet kilka poważnych ciosów (np. wojsko Ras Alula Aba Negga w bitwie pod Dogali), teraz opuściły swoje stanowiska, kierując się przeciwko Mahdystom. W ten sposób Włosi praktycznie bez przeszkód mogli podporządkowywać sobie kolejne obszary.

Menelik II, który pragnałł zostać cesarzem, a nie chciał od samego początku wikłać się w wojnę z Włochami, podpisał w maju 1889 r. słynny traktat Uccialli (od nazwy miejscowości, w której został zawarty), w którym uznał obecność włoską na terenie dzisiejszej Erytrei. W Uccialli ustalono także granice między Etiopia, a terenami zajmowanymi przez Włochów na rzece Mareb (dzisiejsza granica miedzy Etiopią a Erytrea). W listopadzie tegoż roku Menelik II został cesarzem Etiopii, a Włosi w 1890 r. ogłosili powstanie kolonii, nadając jej ponownie nazwę Erytrea.

Podpisując traktat Uccialli, Włosi wcale nie zrezygnowali ze swoich kolonialnych ambicji podporządkowania sobie całej Etiopii. Chcieli tylko, w miarę możliwości, uniknąć zbrojnej konfrontacji. W tym celu użyli podstępu. Traktat był sporządzony w dwóch wersjach językowych: amharskiej i włoskiej. W art. 17 nastapiła rozbieżność językowa, świadomie wprowadzona przez Włochów. W wersji amharskiej była mowa o możliwości korzystania z pomocy włoskiej w sprawach dotyczących stosunków między Etiopia, a innymi krajami. W wersji włoskiej zamiast słowa może użyto musi, więc wg Włochów to oni reprezentowali Etiopię na arenie międzynarodowej, czyli praktycznie objęli nad nią protektorat. Poinformowali o tym społeczność międzynarodową, która w większości (za wyjątkiem Stanów Zjednoczonych i Rosji) uznała ich prawa do całego obszaru Etiopii.

Zaprotestował przeciwko temu Menelik II, informując z kolei świat, że to on jest prawowitym cesarzem oraz wystosował list do króla włoskiego Umberto I, w którym żądał uznania wersji amharskiej traktatu.

W Etiopii istnieje powiedzenie: „Osoby, która udaje, że śpi, nie można obudzić”, co w tym przypadku oznacza, że Włosi, którzy świadomie dokonali oszustwa, trwali przy swojej wersji. Wobec tego Menelik II uznał traktat za nieważny. Nastapiła eskalacja napięcia. Włosi, używając Erytrei jako swojej bazy, rozpoczęli przygotowania do wojny. Gdy zajęli prowincję Tigraj, Menelik II ogłosił pełną mobilizację w całym kraju i już w pierwszej bitwie pod Ambu Alagie Włosi ponieśli druzgocąca klęskę. To bardzo wzmocniło wiarę w zwycięstwo żołnierzy armii etiopskiej, która była liczniejsza, ale bardzo słabo uzbrojona, głównie w tradycyjną broń, tzn. w 
dzidy, miecze, itp. Włosi dysponowali natomiast najnowocześniejszym wówczas sprzętem wojskowym.

Do najsłynniejszej bitwy w historii Afryki przeciwko kolonizatorom, która trwale zaważyła na losie Etiopii doszło 1 marca 1896 r. pod Aduą. O godz. 5:32 stanęły naprzeciw siebie dwie armie: etiopska licząca 73000 słabo uzbrojonych w większości dopiero co wcielonych żołnierzy oraz doskonale uzbrojona, nowoczesna armia włoska licząca 17700 żołnierzy. Bitwa trwała zaledwie kilka godzin. Włosi ponieśli sromotna klęskę. Zginęło 11000 włoskich żołnierzy, a 4000 dostało się do niewoli. Zginęło dwóch włoskich generałów, a dwóch kolejnych dostało się do niewoli. Po stronie etiopskiej straty wynosiły 4000 zabitych i 6000 rannych.

To był prawdziwy szok nie tylko dla Włochów, ale także dla innych mocarstw kolonialnych. Anglicy, którzy do tej pory popierali Włochów, uważając ich za swoich partnerów przeciwko Francuzom, zaczęli wattpić w ich siłę. Po klęsce pod Aduą Włosi zrezygnowali tymczasowo z planów podporządkowania sobie całej Etiopii i wycofali się na tereny dzisiejszej Erytrei. 26 października 1896 r. podpisali traktat pokojowy, regulujący sprawę granic miedzy Etiopią a włoską Erytrea.

Cesarz Menelik II nie wykorzystał swojego zwycięstwa i, niestety, nie poszedł za ciosem, próbując uzyskać dostęp do morza. Na dzisiejszych stosunkach etiopsko-erytrejskich zaważył fakt, że Erytrejczycy czuli się oszukani przez swoich rodaków i pozostawieni na pastwę kolonialnych rządów włoskich.

Zwycięstwo pod Aduą nie tylko dla Etiopczyków, ale także dla wielu Afrykanów stanowiło powód do dumy. Dzięki temu Etiopia jako jedyny kraj w Afryce uniknęła kolonizacji. Dzień 1 marca został ogłoszony świętem narodowym w Etiopii.

Według niektórych Etiopczyków byłoby lepiej, gdyby Włosi zajęli całą Etiopię. Może nie doszłoby wtedy do tak tragicznego w skutkach podziału na Etiopię i Erytreę i udałoby się zachować jedność kraju. Konflikt ten przez dziesiątki lat pochłonął setki tysięcy ofiar i nadal nie został rozwiązany, czego dowodem jest powstanie dwóch oddzielnych państw, ciagły spór między nim i całkowita utrata dostępu do morza przez Etiopię.

Po zwycięstwie pod Aduą cesarz Menelik II, podpisując traktat pokojowy z Włochami, zapewnił sobie pokój na granicy północnej i mógł skoncentrować się na rozszerzeniu granic państwa w kierunku południowym.

Włosi, pomimo przegranej, nigdy nie wyzbyli się marzeń o podbiciu całej Etiopii. Ich kolonialne ambicje osiaggnęły szczyt za faszystowskich rządów Mussoliniego. Pamiętając jednak klęskę, jaką ponieśli, tym razem starannie przygotowali się do kolejnej wojny.

W 1935 roku na terenie Erytrei i Włoskiej Somalii zgromadzili niemal trzystupięćdziesięciotysięczną armię, do której na siłę wcielono także Erytrejczyków, zmuszając ich do bratobójczej wojny. W październiku tegoż roku, uzbrojona po zęby armia włoska uderzyła na Etiopię z dwóch stron. Front północny przekroczył granicę od strony Erytrei i po stoczeniu zaciętych walk zdobył miasto Mekelie (stolica prowincji Tigraj), a front południowy zaatakował od strony Somalii.

Włosi przeciwko słabo uzbrojonym Etiopczykom użyli czołgów, samolotów, a nawet gazów bojowych. Spodziewali się szybkiego i łatwego zwycięstwa. Jednak zaskoczył ich zacięty opór, jaki stawiali broniący swojego kraju Etiopczycy. Dopiero 5 maja 1936 roku Włochom udało się zająć stolicę Addis Abebe. Postanowili wykorzystać ten fakt i ogłosić światu zajęcie całej Etiopii, ale nigdy im się to nie udało. Opanowali tylko duże miasta. Dobrze zorganizowany ruch partyzancki nękał Włochów przez całą okupację i doprowadził do ostatecznego wyzwolenia w 1941r., czemu w znacznej mierze przysłużyli się Brytyjczycy.

Mimo że Erytrejczycy w swojej własnej ojczyźnie traktowani byli jako niewolnicy i praktycznie nie mieli żadnych praw, to jednak w czasie kilkudziesięcioletniego panowania włoskiego obszar ten pod względem gospodarczym (zwłaszcza komunikacyjnym i przemysłowym) rozwiną się o wiele bardziej niż reszta Etiopii. Włosi, chcąc umocnić swoją pozycję na tych terenach, starali się nastawić antagonistycznie Tigrajczyków stanowiących (przeważającą część ludności Erytrei) i Amharów zamieszkujących Etiopię, chociaż obie te grupy wywodzą się z tych samych korzeni i są ze sobą powiązane kulturowo i historycznie. Starali się wpoić Erytrejczykom poczucie odrębności narodowej, po to, aby ci nie współpracowali z Etiopią przeciwko nim. 
Wszystkie działania Włochów sprowadzały się do tego, aby poróżnić oba narody, co bardzo ułatwiłoby im rządy na tych terenach oraz w przyszłości mogło doprowadzić do opanowania całej Etiopii. Z perspektywy dnia dzisiejszego można powiedzieć, że im się to częściowo udało. Zapoczątkowany przez nich konflikt trwa do dziś, chociaż Włosi opuścili te tereny w 1941 roku.

\section{Brytyjczycy w Erytrei}

Po przegranej wojnie 1935-1936, cesarz Hajle Syllasje I wyemigrował do Anglii, gdzie droga dyplomacji zabiegał o interesy swojego kraju, zwłaszcza w Lidze Narodów, do której od początku jej istnienia należała Etiopia.

Początkowo Anglicy akceptowali obecność włoską w Etiopii. Jednak kiedy Włosi przystapili do paktu osi z Niemcami, a następnie wybuchła II wojna światowa, dawni sprzymierzeńcy znaleźli się W stanie wojny. Wtedy Anglicy zaproponowali cesarzowi współpracę. Z pomocą rządu Winstona Churchilla w lipcu 1940 r., Hajle Syllasje I przybył do stolicy Sudanu Chartumu, gdzie w przemówieniu radiowym zwróconym do ludów Etiopii, zapowiedział nadejście zwycięstwa i wyzwolenie kraju spod okupacji włoskiej.

$\mathrm{Na}$ skutek nieufności partyzantów oskarżających cesarza o opuszczenie kraju i bezprawne ogłoszenia zwycięstwa przez nich wywalczonego, Hajle Syllasje I zdecydował się powrócić do Addis Abeby dopiero 5 maja 1941 r., po ostatecznym wycofaniu się wojsk włoskich (wojska brytyjskie wsparły partyzantów jedynie w ostatniej fazie tej operacji).

Jednocześnie wojska brytyjskie zajęły Erytreę i wprowadziło tam zarząd wojskowy. Brytyjczycy pragnęli objąć protektorat nad całą Etiopią, dlatego też jednym z najważniejszych zadań, jakie stanęły przed cesarzem, było uregulowanie stosunków z Wielką Brytanią.

Po zakończeniu II wojny światowej i przegranej Włochów sprawa ich kolonii w Afryce (Erytrea, Somalia, Libia) nabrała rozgłosu międzynarodowego. Szczególnie sprawa Erytrei była bardzo skomplikowana, ponieważ jednocześnie kilka państw rościło do niej prawa. Etiopia powoływała się na powiązania historyczne, kulturowe i etniczne, sięgające zamierzchłych czasów. Włosi domagali się zwrotu swoich kolonii, a Egipcjanie chcieli północnej części Erytrei, zwłaszcza zależało im na porcie Massaua. Każde z ówczesnych mocarstw chciało mieć wpływ w strategicznym miejscu, jakim jest wybrzeże Morza Czerwonego. Dlatego nie doszli do porozumienia ministrowie spraw zagranicznych Francji, Anglii, USA i ZSRR, którzy zebrali się wrześniu 1945 r. w Londynie, aby przedyskutować sprawę dalszych losów tych terenów. Ustalono jedynie, że zostanie powołana specjalna komisja do rozwikłania spornej kwestii.

Tymczasem w Erytrei rodziła się - pod rządami brytyjskimi - świadomość społeczna Erytrejczyków. Zaczęły powstawać partie polityczne o charakterze narodowościowym. Miały one różne poglądy na sprawy niepodległości. Jedne były za połączeniem się Erytrei z Etiopia, inne za utworzeniem suwerennego państwa. Niektóre, w obawie przed dyskryminacją ze strony chrześcijańskiego państwa, chciały wyodrębnienia części muzułmańskiej i przyłączenia jej do Sudanu. Chrześcijanie pragnęli natomiast połączenia z prowincją Tigraj i utworzenia oddzielnego państwa.

W tym czasie energicznie zaczęła działać Etiopia, organizując na terenie Erytrei grupy zwolenników zjednoczenia obu narodów. Nie było to trudne, ponieważ już za czasów kolonii włoskiej było ich wielu, a przybyło jeszcze więcej w momencie opuszczenia Erytrei przez Włochów. W 1941 r. powstała grupa o nazwie Fikre Hager Maheber, czyli Zwiazek Miłośników Ojczyzny, która dała początek Partii Jedności, utworzonej w 1944 r., a finansowanej przez rząd etiopski.

Okres administracji brytyjskiej można nazwać czasem tworzenia się świadomości narodowej Erytrejczyków, a zarazem narastania różnic światopoglądowych, które podzieliły społeczeństwo. Brytyjczycy chcąc zachować swoje wpływy w tym rejonie, jak również bojąc się wzrostu wpływów etiopskich, pośrednio lub bezpośrednio przyczyniali się do powstawania coraz to nowych partii, aby osłabić naród, bo jak wiadomo, podzielonym narodem rządzi się łatwiej. Dlatego obok Partii Jedności powstały inne, takie jak: Partia Prowłoska, która była za powrotem kolonii włoskiej, Liberalna Partia Rozwoju, która popierała administrację brytyjska, partia o nazwie Rabit El-Islamia, która nawoływała do przyłączenia części muzułmańskiej do Sudanu. 
Przyszłość Erytrei była wciąż niepewna. W tej sytuacji cztery wielkie mocarstwa: USA, Francja, Anglia i ZSRR powołały Komisję Badawczą d.s. Erytrei, Somalii i Libii, czyli dawnych kolonii włoskich. We wrześniu 1947 r. przedstawiciele tej komisji przybyli do Erytrei, ale mimo usilnych starań, nie potrafili dojść do kompromisu, i dlatego 15 września 1948 r. sprawę przedstawiono na forum Zgromadzenia Ogólnego. Chociaż problem Libii i Somalii udało się rozwiązać, to w sprawie Erytrei uznano potrzebę dalszych badań. Powołano wiec kolejną komisję tym razem przy ONZ. W skład tej komisji weszli przedstawiciele Norwegii, Afryki Południowej, Birmy, Pakistanu i Gwatemali. Po zbadaniu sprawy na miejscu, członkowie komisji przedstawili kilka propozycji: przedstawiciele Birmy i Afryki Południowej chcieli utworzenia federacji etiopsko-erytrejskiej, delegacja z Pakistanu i Gwatemali proponowała niepodległość Erytrei, a Norwegia za najlepsze rozwiązanie uznała włączenie Erytrei do Etiopii. Propozycje te złożyli Sekretarzowi Generalnemu ONZ.

Niezależnie od tej komisji Etiopia złożyła w ONZ własną propozycję połączenia obu państw. Za najlepsze rozwiazanie uznano utworzenie federacji etiopsko-erytrejskiej pod zwierzchnictwem korony etiopskiej. Na V Sesji Zgromadzenia Ogólnego 2 grudnia 1950 r. podjęto rezolucję 390 A (V) o włączeniu Erytrei w skład Etiopii, jako autonomicznej prowincji z własnym parlamentem i rządem.

Aby zagwarantować przestrzeganie uchwalonej rezolucji, wysłano dyplomatę boliwijskiego dr Eduardo Anze Matienzo w celu przygotowania odpowiedniej konstytucji dla Erytrei, która w lipcu 1952 r. uchwalił parlament Erytrei, a miesiąc później ratyfikował cesarz Hajle Syllasie I. Następnie został powołany rząd erytrejski i Erytrejskie Zgromadzenie Narodowe. We wrześniu tegoż roku cesarz ratyfikował Akt Federacyjny. 15 września 1952 r. weszła w życie uchwała ONZ. Datę tę oficjalnie uznaje się za dzień powstania federacji etiopsko-erytrejskiej. Następnego dnia Sir Duncan Cumming, który był ostatnim zarządcą brytyjskim Erytrei, podpisał odpowiedni akt w imieniu rządu Wielkiej Brytanii. W ten sposób zakończył się brytyjski zarząd wojskowy nad Erytreą. Erytrea oficjalnie powróciła do Etiopii.

Jednak zwolennicy, zjednoczenia z Etiopią opanowali parlament erytrejski. Opozycjoniści, wśród nich najbardziej znani Woldeab Wolde Mariam oraz Ibrahim Sultan, którzy bronili autonomii zmuszeni zostali do emigracji. Pierwszy premier Erytrei - Tedla Bairu, musiał zrezygnować ze swojego stanowiska, a jego miejsce zajął zwolennik cesarza - Asfaha Wolde Michael. Dotychczasowe języki urzędowe: tigrinia i arabski zostały zastapione amharskim, a flaga Erytrei flagą Etiopii. Wprowadzono ścisłą cenzurę prasy, rozwiązano partie polityczne oraz związki zawodowe.

Wszystkie te działania miały na celu wcielenie Erytrei do Etiopii. Zdesperowani Erytrejczycy widząc swoją bezsilność, zaczęli opuszczać kraj. Ostatecznie, 15 listopada 1962 r. parlament erytrejski złożony głównie ze zwolenników cesarza oraz zastraszonej opozycji przegłosował ustawę likwidującą federację. Erytrea stała się czternastą prowincją Etiopii. Opozycja złożyła w tej sprawie protest do ONZ, ale nie odniósł on większych skutków, ponieważ to cesarz Hajle Syllasie I cieszył się większym poparciem na arenie międzynarodowej, zwłaszcza ze strony USA, ponieważ pozwolił na założenie w okolicy Asmare (stolica Erytrei) największej w tym rejonie bazy wojskowej - Kagnew Base. Moment wcielenia Erytrei w skład Etiopii można uznać za iskrę, która spowodowała wybuch otwartego konfliktu etiopsko - erytrejskiego, który trwał przez następnych 30 lat.

\section{Walka zbrojna o niepodległość Erytrei}

Niezadowoleni Erytrejczycy, widząc, że cesarz dąży do całkowitego podporządkowania sobie Erytrei, zaczęli tworzyć grupy antyetiopskie. Już w latach 50-tych powstał Eritrean Liberation Movment (ELM), czyli Erytrejski Ruch Wyzwolenia, który działał w sposób dyplomatyczny i sam w sobie nie odegrał większego znaczenia, jednak zapoczątkował zbrojny ruch antyetiopski.

Od początku powstania federacji, muzułmanie którzy wyemigrowali do państw arabskich, aktywnie działali na rzecz niepodległości. Byli oni tam serdecznie przyjmowani głownie z trzech powodów. Po pierwsze, wyznawali tę samą religię, a ich muzułmańskim braciom przeszkadzało, że muszą żyć pod rządami chrześcijańskiego monarchy. Po drugie, ogłosili Erytreę krajem arabskim. Po trzecie, Etiopia prowadziła proamerykańską i proizraelską politykę, czyli współpracowała z 
wrogami państw arabskich. Arabowie obawiali się, że wybrzeże Morza Czerwonego znajdzie się w zasięgu wpływów amerykańskich, dlatego wspomagali Erytrejczyków moralnie i finansowo.

W 1960 r. w Kairze doszło do spotkania najbardziej aktywnych działaczy niepodległościowych mieszkających na emigracji na Bliskim Wschodzie. Zdecydowali oni o rozpoczęciu akcji zbrojnej na terenie Erytrei przeciwko Etiopii. W 1961 r. utworzono Eritrean Liberation Front (ELF), czyli Erytrejski Front Wyzwolenia oraz jego zbrojne skrzydło Eritrean Liberation Army (ELA), czyli Erytrejska Armię Wyzwolenia. Przywódcą tych ugrupowań został Mohamed Idris. Ugrupowanie to rozpoczęło tzw. najdłuższą wojnę w Afryce. Ruch ten działał na zasadzie partyzantki, głównie w rejonach graniczących z Sudanem. Rząd etiopski zbagatelizował ich działalność. Jednak, kiedy rozpoczęli akcje terrorystyczne, podjęto działania odwetowe. Paradoksalnie, działania te jeszcze bardziej wzmocniły Erytrejska Armię Wyzwolenia, ponieważ wojsko etiopskie, nie mogąc bezpośrednio dotrzeć do partyzantów, pacyfikowało całe wioski, zastraszało ludność, co powodowało, że mieszkańcy tych rejonów masowo przyłączali się do partyzantów. Zwiększyła się także zagraniczna pomoc finansowa dla walczących. Do wielkich sprzymierzeńców takich jak Libia, Irak, Iran czy Syria, dołączyły państwa socjalistyczne ze Związkiem Radzieckim i Chinami na czele. Starały się one w ten sposób przeciwstawić dominacji USA w tym rejonie.

W samym Erytrejskim Froncie Wyzwolenia istniał podział ze względu na przynależność religijna, ideologiczna, etniczną i regionalną, który doprowadził do wyodrębnienia się różnych frakcji. Jedną z nich była frakcja chrześcijańska o orientacji socjalistycznej. Przyjęła ona początkowo nazwę Erytrejski Front na Rzecz Niepodległości. Działał ona głównie w rejonie Akele Guzaj. Jej liderem został Isajas Afewerki, późniejszy prezydent Erytrei. Następny odłam pod nazwą Sekretariat Generalny utworzył w Bejrucie Osman Sabbe z jego zbrojnym skrzydłem People's Liberation Forces (PLF), czyli Ludowe Siły Wyzwolenia. Działał on głównie na wybrzeżu Morza Czerwonego. Inna grupa to Obelites, która działała na nizinnych terenach w okolicy Barka. Skupiała ona przeważnie ludność plemienia Beni - Amer.

Każde z tych ugrupowań działało osobno, jednak po długich negocjacjach zdecydowali się współpracować w walce przeciwko wspólnemu wrogowi. W styczniu 1972 r. na spotkaniu w Bejrucie zdecydowano o powstaniu Eritrean Liberation Front - Popular Liberation Forces (ELF PLF), czyli Erytrejski Front Wyzwolenia - Ludowe Siły Wyzwolenia. Pomimo, że działały one w jednej organizacji, każda $\mathrm{z}$ tych trzech grup przyjęła oddzielną nazwę i tak: grupa Osmana Sabbe PLF I, grupa Isajasa Afewerki PLF II, a grupę Obelites nazwano Obelites - ELF.

Jednak współpraca owych grup nie trwała długo. Wkrótce zaczęły się wzajemnie zwalczać. Dodatkowo Erytrejski Front Wyzwolenia, ich macierzysta organizacja, której w tym czasie przywódcą był Tedla Bairu, były premier Erytrei, wystapiła zbrojnie przeciwko nim. Zadała ona poważny cios ugrupowaniu Osmana Sabbe i Obelites, natomiast grupie Isajasa Afewerki udało się uniknąc z nim starcia, dlatego z dnia na dzień stała się ona najsilniejszym ugrupowaniem. Jego program o orientacji socjalistycznej oraz głoszone przez niego hasła niepodległościowe stały się bardzo atrakcyjne, zwłaszcza dla ludzi młodych, wykształconych i dynamicznych. Oprócz działających w niej chrześcijan udało im się przyciagnąć do siebie także muzułmanów, którzy odcinali się od fanatyzmu religijnego. Uzyskali poparcie emigracji erytrejskiej mieszkającej w Ameryce Północnej i Europie, po ich stronie opowiedziały się także państwa socjalistyczne.

W 1973 roku grupy Isajasa Afewerki i Osmana Sabbe znów się połączyły i utworzyły Eritrean People's Liberation Forces (EPLF), czyli Front Wyzwolenia Ludu Erytrei. W ten sposób Isajas Afewerki zajął dominującą pozycję wśród liderów ugrupowań niepodległościowych. Konflikt miedzy Frontem Wyzwolenia Ludu Erytrei i Frontem Wyzwolenia Erytrei nadal trwał i przyjął formę ostrej walki politycznej oraz zbrojnej.

Do czasu upadku cesarza Hajle Syllasie I w 1974 r. ugrupowania niepodległościowe działały na zasadzie partyzantki i nie było mowy o otwartej wojnie. W Etiopii nazywano ich bandytami, a rząd ich lekceważył.

W 1974 r. niezadowolone z rządów wojsko, przy poparciu społeczeństwa, obaliło cesarza Hajle Syllasie I i na jego miejsce powołano Provisional Military Administration Council (PMAC), czyli tzw. Derg (z języka amharskiego), który kierowany był przez pułkownika Mengystu Hajle Mariam (zwanego powszechnie Mengystu). W Dergu nie istniała początkowo jasno określona 
opcja polityczna. Jego głównym celem była detronizacja cesarza. Stany Zjednoczone, które były głównym sojusznikiem cesarza, nie poparły nowego rządu oraz odmówiły dostaw broni. Dlatego Derg zwrócił się o poparcie do państw socjalistycznych: początkowo do Chin, a później do ZSRR. Derg ogłosił Etiopię państwem socjalistycznym i wprowadził ideologię marksistowskoleninowską. Wiele wskazuje na to, że Etiopia mogła uniknąć systemu socjalistycznego, który to pochłonął dziesiątki tysięcy ludzkich ofiar z powodu czystek ideologicznych, gdyby USA poparły Mengystu.

Derg oficjalnie przyznał, że problem Erytrei jest sprawą poważną. Skoro najbardziej liczące się ugrupowania niepodległościowe w Erytrei miały charakter lewicowy i popierane były przez państwa socjalistyczne, to wierzono, że istnieje szansa na rozwiązanie pokojowe. Mengystu świadomie wycofał się ze stanowiska wiceprzewodniczacego, chociaż de facto był przywódca, a na przewodniczącego Dergu i zarazem ministra obrony narodowej, powołano Erytrejczyka, gen. Amana Andoma, który rozpoczął negocjacje pokojowe. Jego popularność wśród społeczeństwa i wojska rosła, co nie podobało się Mangystu. 23 listopada 1974 r. Aman Andom został zamordowany. W tym dniu rozstrzelano także 60 wysokiej rangi urzędników z rządu cesarza.

W czasie, gdy w Etiopii trwały czystki polityczne i próby negocjacji z partyzantami, w Erytrei zapanował względny spokój, co dało czas ugrupowaniom niepodległościowym na przygotowanie się do wojny. W lutym 1975 r. partyzanci otoczyli Asmarę stolicę Erytrei. Po raz pierwszy doszło do otwartej bitwy. To już nie byli partyzanci, ale regularne wojsko. Jednak ponieśli poważną klęskę, tracąc setki żołnierzy. Obie strony rozpoczęły przygotowania do wojny, bo stało się jasne, że nie ma szans na rozwiązanie pokojowe.

Derg ogłosił w całym kraju mobilizację. Powołano setki tysięcy chłopów, przede wszystkim z prowincji Shoa, Godżam, Tigraj i Gonder. W marcu 1976 r. wysłano pierwszy turg - sto tysięcy uzbrojonych $\mathrm{w}$ przestarzałe karabiny chłopów, którzy samą swoją masą mieli zgnieść Erytrejczyków oraz wszystkie inne ugrupowania, sprzeciwiające się nowym rządom. Nazwano to czerwonym marszem. Jednak nie dotarli oni nawet do granicy Erytrei, ponieważ zostali zaatakowani przez Tigray People's Liberation Front (TPLF), czyli Tigrajski Ludowy Front Wyzwolenia, który współpracował z Erytrejczykami. Ostatecznie zostali oni rozbici przez Front Wyzwolenia Ludu Erytrei w okolicy Zalambesa.

Po fiasku czerwonego marszu rząd postanowił spróbować negocjacji. 16 maja 1976 r. ogłosił dziesięciopunktowy plan pokojowy, opierający się głównie na amnestii i rehabilitacji rebeliantów oraz na ogłoszeniu autonomii Erytrei w ramach federacji z Etiopią. Partyzanci sprytnie podeszli do tego planu. Wysłano kilku z nich, aby w ramach skruchy podjęli współpracę z rządem Mengystu. Ci po zebraniu informacji, wrócili do swoich oddziałów.

Powstanie w prowincji Tigraj w lutym 1975 r. Tigrajskiego Ludowego Frontu Wyzwolenia, bardzo wzmocniło Front Wyzwolenia Ludu Erytrei. Choć miał on orientację socjalistyczna, dla wielu program tej organizacji nie był jasny: czy chodzi o autonomię dla prowincji Tigraj, czy też o pełną niepodległość. Jedno było wiadomo: jej przywódca Meles Zenawi (późniejszy premier Etiopii) i przywódca Frontu Wyzwolenia Ludu Erytrei Isajas Afewerki (późniejszy prezydent Erytrei) byli nie tylko przyjaciółmi, ale także krewnymi. Wszystkie ich działania przeciwko Mengystu były wspólnie planowane. Rząd Etiopii zmuszony został do prowadzenia działań wojennych, w tym również bombardowań ludności cywilnej nie tylko w Erytrei, ale także w prowincji Tigraj. Erytrejczycy i Tigrajczycy, którzy mieszkali w różnych regionach Etiopii, a nawet ci, którzy współpracowali z rządem, podejrzewani byli o nielojalność i prześladowani. Wszystko to powodowało, że do partyzantów przyłączało się coraz więcej ochotników.

W całym kraju zaczęło narastać niezadowolenie z komunistycznego, wojskowego rządu Mengystu. Reakcją władz był tzw. czerwony terror, czyli brutalne likwidowanie przeciwników rewolucji. Najbardziej narażona była młodzież i inteligencja. Nawet w Addis Abebie w biały dzień słychać było strzały, a na ulicach leżały zwłoki brutalnie zamordowanych. Okrucieństwo, do jakiego się posuwano w walce o utrzymanie władzy, trudno jest opisać. Ludzie żyli w ciagłym strachu*).

\footnotetext{
*) Pamiętam, że kiedy w Addis Abebie zastrzelono mojego bliskiego kolegę w miejscu jego pracy, chcący odzyskać ciało syna rodzice musieli zapłacić za kulę, która go zabiła. Innym znajomym zabito dwóch synów
} 
Wszystkie te działania zamiast osłabić tylko wzmocniły Front Wyzwolenia Ludu Erytrei i Tigrajski Ludowy Front Wyzwolenia. Erytrejczycy i Tigrajczycy masowo uciekający przed prześladowaniami i śmiercią, wstępowali do tych organizacji. Działania rządu w czasie czerwonego terroru na tzw. zagrożonych terenach, czyli w Tigraj i Erytrei były jeszcze bardziej brutalne i zdecydowane. Rzeczywistą kontrolę rząd Mengystu sprawował jedynie w większych miastach, reszta terenu opanowana była przez partyzantów, ludność zaczęła więc opuszczać miasta (w Asmarze w okresie 1974 - 1977 liczba mieszkańców zmniejszyła się z ponad dwustu do dziewięćdziesięciu tysięcy).

Był to bardzo trudny czas dla rządu Mengystu. Zgodnie z amharskim powiedzeniem chory na tarczyce dodatkowo zachorowat na świnkę (czy też: nigdy nie jest tak źle, żeby nie mogło być gorzej), wybuchła wojna z Somalią. Rząd Somalii, widząc, że Etiopia uwikłała jest w wewnętrzne konflikty, które ją osłabiały, postanowiła wykorzystać sytuację, i wysunąć roszczenia terytorialne do wschodnich prowincji. W dniu 23 lipca 1977 roku wojska somalijskie uderzyły na Etiopię, wkraczając w głąb jej terytorium nawet do $700 \mathrm{~km}$. Mengystu wezwał cały naród do powszechnej mobilizacji pod hasłem: Socjalistyczna Matka Ojczyzna albo śmierć. Sprawa obrony kraju dla Etiopczyków zawsze była sprawą honoru, dlatego wewnętrzne spory zeszły na drugi plan i naród zjednoczył się $\mathrm{w}$ walce $\mathrm{z}$ najeźdźcą $\mathrm{W}$ krótkim czasie zorganizowano trzystutysięczną armię, składającą się głownie z chłopów. Pomocy udzielił też ZSRR, dostarczając najlepszy sprzęt wojskowy, oraz Kuba i Jemen, które przysłały swoich doradców. W ciagu kilku miesięcy armia somalijska została wyparta $\mathrm{z}$ okupowanych terenów, pozostawiając większość sprzętu wojskowego.

W czasie, gdy rząd zajęty był wojną z Somalia, partyzantom erytrejskim udało się powiększyć obszar przez siebie kontrolowany. W rękach Mengystu pozostała tylko stolica Asmara, port Assab i miasto Barentu. Jednak zwycięstwo nad Somalią bardzo wzmocniło jego pozycję. W 1978 roku rzucił on dobrze wyposażone wojska przeciwko partyzantom i zmusił ich do opuszczenia wcześniej zajętych miast. Jednak nadal kontrolowali oni prowincję, ponieważ w trudno dostępnym, górzysty terenie praktycznie byli nie do pokonania. Pomimo odnoszonych sukcesów do wielu członków rządu a także do społeczeństwa, zaczęło coraz wyraźniej docierać, że problemu tego nie można rozwiązać militarnie i należy spróbować innych sposobów.

W 1982 r. Derg postanowił rozpocząc w Asmarze akcję pod nazwą Obóz Czerwonej Gwiazdy. Sam Mengystu przeniósł tam tymczasowo swoją siedzibę oraz najważniejsze organy władzy. Ściągnął najlepszych architektów, artystów, inżynierów, znanych dziennikarzy, aby uzyskać z ich strony poparcie dla swoich działań. W całym kraju propaganda głosiła hasła ostatecznego rozwiązania problemu odbudowy Erytrei. Nieoficjalnie akcję tę nazwano: Multi - Faced Campaign czyli Obóz o różnych twarzach. Z jednej strony festyny, akademie i odbudowa zniszczeń, z drugiej eksterminacja i przygotowania do kolejnej ofensywy. W krótkim czasie liczba żołnierzy etiopskich stacjonujących w Erytrei wzrosła do dwustu tysięcy. Tej ogromnej armii przeciwstawiło się zaledwie siedemnaście tysięcy żołnierzy erytrejskich. Jednak w górzystym terenie nie byli oni bez szans. Mając opanowane strategiczne punkty, nawet niewielka liczba żołnierzy mogła zatrzymać całą armię. Front posuwał się naprzód bardzo powoli. Każde najdrobniejsze zwycięstwo, Etiopczycy okupowali nieproporcjonalnie ogromnymi stratami. W końcu udało im się otoczyć główna bazę partyzantów Nacfa. Stanęli przed niepowtarzalną szansą zadania Erytrejczykom ostatecznego ciosu. Zdając sobie sprawę z historycznego znaczenia tego wydarzenia, chciano, aby Nacfa została zdobyta przez macierzystą II Dywizję Mengystu. Stacjonowała ona jednak w odległej prowincji.

Oczekując jej przybycia, oddziały erytrejskie miały czas na przegrupowanie i nieoczekiwanie przebiły kordon otaczających je wojsk rządowych, zadając im śmiertelny cios. Ofensywa ta kosztowała Etiopię jedenaście tysięcy zabitych, tysiące rannych i wziętych do niewoli. Po klęsce tej, niepodległość Erytrei była już tylko kwestią czasu. Sam Mengystu stracił nadzieję na zwycięstwo i wrócił do Addis Abeby. Nastapiła całkowita demoralizacja wojska. W 1989 roku

w ich własnym domu na oczach matki i kazano jej posmarować twarz ich krwią. Ja sam ze strachu musiałem przerwać szkołę, ponieważ bałem się wychodzić z domu, w którym i tak nie było bezpiecznie (przypis autora). 
Tigrajski Ludowy Front Wyzwolenia, która praktycznie panowała w prowincji Tigraj połączyła się z innymi mniejszymi ugrupowaniami antyrządowymi i utworzyła Ethiopian People's Revolutionary Democratic Front (EPRDF), czyli Etiopski Ludowo-Rewolucyjny Front Demokratyczny. Razem z Erytrejczykami rozpoczęli ofensywę antyrządową. W 1990 roku praktycznie większość strategicznych punktów w Erytrei, w tym port Massaua, znajdowały się w rękach Erytrejczyków. Utrata portu była szokiem dla rządu i ostatecznie przypieczętowała klęskę.

Mengystu Hajle Mariam 21 maja 1991 r. uciekł do Zimbabwe. Stolica Erytrei Asmara została zdobyta 26 maja, dzień później zaś Etiopski Ludowo-Rewolucyjny Front Demokratyczny wkroczył do Addis Abeby. Utworzono rząd tymczasowy, na czele którego stanął Melese Zenawi. Tym samym zakończono trwająca blisko 30 lat wojnę oraz krwawe rządy komunistyczne. Etiopia całkowicie straciła dostęp do morza, a wkrótce miało powstać nowe państwo - Erytrea.

Można wymienić wiele przyczyn, które doprowadziły do upadku rządu Mengystu i do całkowitego oderwania się Erytrei od Etiopii. Jedna z nich było wymordowanie najbardziej doświadczonych i wykształconych generałów i dowódców, którzy śmieli watpić w słuszność decyzji rządu.

W 1989 r. generałowie z wojska i policji w czasie wizyty Mengystu w NRD zorganizowali przewrót wojskowy, który się nie powiódł. Przywódców buntu aresztowano, setki innych oficerów zamordowano, uwięziono lub zwolniono ze stanowisk. Ich miejsce zajęli niedoświadczeni, ale lojalni oficerowie. Dziesiątki tysięcy niezadowolonych żołnierzy zaczęło dezerterować do Sudanu lub wstępować do organizacji antyrządowych, nawet do Frontu Wyzwolenia Ludu Erytrei. Chcąc wprowadzić porządek $\mathrm{w}$ wojsku, dla przestrogi $\mathrm{w}$ pierwszą rocznicę przewrotu stracono 12 generałów.

Kolejną przyczyną upadku Mengystu był koniec zimnej wojny i rozpad bloku państw socjalistycznych, które były głównymi sojusznikami i dostawcami broni.

Poza tym oprócz krajów arabskich, także państwa zachodnie, a zwłaszcza Stany Zjednoczone popierały (również finansowo) działalność antykomunistyczną i antyrządowa, chcąc osłabić nieprzychylny im rząd.

Narastało również niezadowolenie społeczne z rządów Mengystu i stale pogarszającego się stanu gospodarki.

Erytrejczycy mieli zaś tylko jeden cel - uzyskanie niepodległości. W przypadku przegranej musieli umrzeć albo udać się na emigrację. Natomiast wojsko etiopskie, które powstało poprzez ogólnonarodową mobilizację i składało się głownie z chłopów, nie miało takiej motywacji. Im zależało na tym, aby wojna jak najszybciej się skończyła, bez względu na wynik.

\section{Powstanie państwa erytrejskiego i narastanie kolejnego konfliktu}

Od momentu przejęcia Asmary 26 maja 1991 r. można powiedzieć, że Erytrea nieformalnie stała się suwerennym, niepodległym państwem. Utworzony został rząd tymczasowy z Isajasem Afewerki na czele. Jednak z ogłoszeniem tego faktu zwlekano aż dwa lata, za oficjalną przyczynę podając, że należy przygotować społeczeństwo, które samo miało zdecydować o swojej przyszłości w drodze referendum. Rzeczywistą zaś przyczyną był brak odpowiedniego przygotowania, niewydolność organizacyjna, zrujnowana gospodarka. Wzajemne powiązania obu państw były tak silne, że trudno było je rozdzielić. Tym bardziej, że liderzy tych państw nie tylko wspólnie obalali rząd Mengystu, ale także byli kuzynami. Bardzo liczono na ich przyjaźń, która miała być gwarantem stabilizacji w tym, zapalnym rejonie świata. Obaj przywódcy byli młodzi, wiele podróżowali po świecie, zetknęli się z demokracjami państw zachodnich. Świat miał prawo wierzyć, że staną się modelowym przykładem demokracji dla reszty Afryki. Etiopia miała swobodny dostęp do portów, w zamian Erytrea zachowała wspólną walutę ułatwiającą rozliczenia. Pomoc z Etiopii cały czas napływała, począwszy od maszyn do pisania, a skończywszy na bombowcach. Nawet Etiopski Bank Narodowy przesyłał pieniądze do Erytrejskiego Banku Narodowego, a tych którzy się temu sprzeciwiali zwalniano. Dzięki tym działaniom gospodarka erytrejska, w krótkim czasie podźwignęła się z ruiny.

Jednak w tym doskonałym układzie dość szybko coś zaczęło się psuć. Część społeczeństwa etiopskiego, zwłaszcza intelektualiści, głośno zaczęli mówić, że nigdy nie pogodzą się z utratą Erytrei, i że widzą poważne zagrożenie dla funkcjonowania gospodarki w przypadku braku dostępu 
do morza. Oskarżali zdominowany przez Tigrajczyków rząd, że ułatwia Erytrejczykom oderwanie się od macierzystego kraju. Poza tym ludność wielonarodowej Etiopii przyzwyczaiła się do rządów władców z plemienia Amhara, którzy przez wieki sprawowali władzę w tym kraju. I chociaż rząd z całą odpowiedzialnością można uznać za najlepszy z dotychczasowych, to i tak przez Amharów i część Oromo - najliczniejsze grupy etniczne oraz inne ludy, nie został zaakceptowany, ponieważ czuły się one dyskryminowane w nowych warunkach.

Demokracja panująca w tym czasie w Etiopii pozwalała na zadawanie trudnych pytań pod adresem rządu. Społeczeństwo pytało więc: Dlaczego akceptować podział kraju? Dlaczego pomagać Erytrejczykom, skoro wcześniej z nimi walczyliśmy? Zaczęto oskarżać premiera Melesa Zenawi, że nie działa w interesie swojego kraju i pozwala na zbyt dużą ingerencję Erytrejczyków w życie gospodarcze i polityczne kraju.

Tymczasem Erytrejczycy coraz liczniej dostarczali Etiopczykom powodów do oburzenia. Ludzie zdawali sobie sprawę, że wojsko etiopskie część zajmowanych terenów oddało bez walki, w ten sposób przejęto np. Asmarę. Dlatego nie mogli zrozumieć, dlaczego żołnierzy, którzy dostali się do niewoli traktowali z takim okrucieństwem, masowo mordowano zwłaszcza oficerów. Tym, którym darowano życie wysyłano do Etiopii, część z nich ogałacając dosłownie ze wszystkiego, wyrywając im złote zęby. A przecież żołnierze ci, w przeważającej części byli prostymi chłopami, zmuszonymi do w walki przez komunistyczny rząd wbrew swoim przekonaniom i nie czuli do Erytrejczyków nienawiści. Represje dotknęły także ludność cywilną: około sto tysięcy Etiopczyków zmuszono do opuszczenia Erytrei. rozdzielono małżeństwa mieszane. Starano się zatrzeć wszelkie ślady powiązania z Etiopia, choć jest to niemożliwe, ponieważ wspólne korzenie historyczne i religijne sięgają zamierzchłych czasów. Eksponowano przede wszystkim różnice. To wszystko powodowało atmosferę wzajemnej wrogości, tym bardziej, że prawie każda rodzina etiopska straciła kogoś w tej wojnie.

Jednocześnie, z wypowiedzi przywódcy Erytrei Isajasa Afewerki można było wywnioskować, że został zakończony tylko pewien etap i że jego celem było powiększenie terytorium. A miał ku temu wiele powodów.

Po pierwsze, po wojnie została ogromna liczba kombatantów i weteranów, którzy nie potrafili odnaleźć się w nowej rzeczywistości. Zrujnowany kraj nie mógł im zapewnić pracy ani godnego życia. Czuli się rozczarowani i dlatego coraz mocniej naciskali na rząd. W 1994 r. doszło do demonstracji antyrządowej, podczas której zastrzelono trzech byłych żołnierzy. Chcąc odwrócić ich uwage od spraw gospodarczych rząd, wymyślał coraz to nowe roszczenia pod adresem sąsiadujących państw, karmiąc naród fałszywymi hasłami propagandowymi.

Po drugie, Erytrejczycy wierzyli, że mają najsilniejszą armię w tym rejonie, ponieważ z czasów wojny pozostał im sprzęt wojskowy. Uważali, że są w stanie pokonać każdego. Butnie głosili, że Sudan jest niestabilny, Etiopia podzielona, Dżibuti beznadziejne, a Jemen rządzony przez rywalizujących ze sobą lokalnych dowódców. Uznawali siebie za żandarma Rogu Afryki, zdolnego do wszelkiej interwencji. Najpierw pokłócili się z Sudanem o to, że wspiera antyrządową erytrejską opozycję islamska, następnie w grudniu 1995 r. zajęli wyspy Hanisz, które Jemen uważał za swoje, w kwietniu 1996 r. weszli ok. 7 km w głąb terytorium Dzibuti, jednak szybko się stamtąd wycofali. Nigdy nie przyznali się do tego, że przestraszyli się konfliktu z Francja, której wojska ochraniają Dżibuti. W ten sposób stali się jedynymi w Afryce, którzy oficjalnie sprzeciwiali się obecności francuskiej w tym kraju.

Po trzecie, rząd Melesa Zenawi uważał, że ma w Erytrei najlepszego z możliwych sojuszników i dlatego zaraz po wojnie, bojąc się o swoją pozycję, rozwiązał półmilionową armię Mengystu. Erytrejczycy natomiast, pomimo trudnej sytuacji gospodarczej, wciąż udoskonalali swoją.

Wkrótce zaczęły pogarszać się stosunki między Melesem Zenawi a Isajasem Afewerki. Zaostrzyły się one jeszcze bardziej w listopadzie 1997 r., kiedy Erytrea wprowadziła własną walutę nacfa oraz znacznie podniosła opłaty za korzystanie z portów, żądając rozliczeń w dolarach.

Śledząc te wydarzenia łatwo było przewidzieć, że wcześniej czy później Erytrea znajdzie jakiś pretekst do konfliktu z Etiopią. Pomimo to jej agresja na Etiopię całkowicie zaskoczyła świat, który zupełnie nie był przygotowany na taki obrót spraw. Wybuchła wojna etiopsko-erytrejska. 


\section{Literatura}

Arnold, S. 1982. Dzieje świata. Ludowa Spółdzielnia Wydawnicza.

Bartnicki, A., Mantel-Niećko, J. 1987. Historia Etiopii. Wrocław.

Bułatowicz, A. 2000. Z wojskami Menelika II. Warszawa.

Dawit Wolde Giorgis 1989. Red Tears. New Jersey.

Mantel-Niećko, J. 1975. Etiopia, podstawowe wiadomości o kraju, jego dziejach i historii badań. Warszawa.

Mesfin Wolde Mariam 1986. Rural Vulerability to Famine in Ethiopia 1958-1977. London.

Pankhurst, R. 1977. Z kraju królowej Saby. Warszawa.

Prokopczyk, J. 1964. Historia Afryki w zarysie. Warszawa.

Tekeste Negash 1987. Italian Colonialism in Eritrea 1882-1941. Uppsala.

Testfasion Medhanie 1986. Erytrea. Amsterdam. 